\title{
MOLECUlar Systematics AND EVOLUTION OF THE CYANOCORAX JAYS
}

\author{
Elisa Bonaccorso $^{a, b^{*}}$, A. Townsend Peterson ${ }^{b}$, Adolfo G. Navarro-Sigüenza ${ }^{c}$, \\ and Robert C. Fleischer ${ }^{d, e}$
}

${ }^{a}$ Museo de Zoología de Vertebrados QCAZ, Facultad de Ciencias Exactas y Naturales, Pontificia Universidad Católica del Ecuador, Av. 12 de Octubre 1076, Quito, Ecuador. E-mail: elisab@ku.edu Phone: (593) 2-2991700 ext. 1069

${ }^{b}$ Natural History Museum and Biodiversity Research, University of Kansas, 1345 Jayhawk Boulevard, Lawrence KS 66045, USA

${ }^{c}$ Museo de Zoología “Alfonso L. Herrera,” Facultad de Ciencias, Universidad Nacional Autónoma de México, Apartado Postal 70-399, D.F. 04510, México

${ }^{d}$ Genetics Program, National Museum of Natural History and National Zoological Park, Smithsonian Institution, 3001 Connecticut Avenue, NW, Washington, DC 20008, USA

${ }^{e}$ Division of Birds, National Museum of Natural History, Smithsonian Institution, Washington, DC 20526, USA

* Corresponding author 
Abstract. Phylogenetic relationships were studied in the genus Cyanocorax (Aves: Corvidae) and related genera, Psilorhinus and Calocitta, a diverse group of New World jays distributed from the southern United States south to Argentina. Although the ecology and behavior of some species in the group have been studied extensively, lack of a molecular phylogeny has precluded rigorous interpretations in an evolutionary framework. Given the diverse combinations of plumage coloration, size, and morphology, the taxonomy of the group has been inconsistent and understanding of biogeographic patterns problematic. Moreover, plumage similarity between two geographically disjuct species, the Tufted Jay (Cyanocorax dickeyi) from western Mexico and the White-tailed Jay (C. mystacalis) from western Ecuador and Peru, has puzzled ornithologists for decades. Here, a phylogeny of all species in the three genera is presented, based on study of two mitochondrial and three nuclear genes. Phylogenetic trees revealed the non-monophyly of Cyanocorax, and the division of the whole assemblage in two groups: "Clade A" containing Psilorhinus morio, both species in Calocitta, Cyanocorax violaceus, C. caeruleus, C. cristatellus, and C. cyanomelas, and "Clade B" consisting of the remaining species in Cyanocorax. Relationships among species in Clade A were ambiguous and, in general, not well resolved. Within Clade B, analyses revealed the monophyly of the "Cissilopha" jays and showed no evidence for a sister relationship between C. mystacalis and C. dickeyi. The phylogenetic complexity of lineages in the group suggests several complications for the understanding biogeographic patterns, as well as for proposing a taxonomy that is consistent with morphological variation. Although multiple taxonomic arrangements are possible, recommendations are for recognizing only one genus, Cyanocorax, with Psilorhinus and Calocitta as synonyms.

Key words: Cyanocorax, Psilorhinus, Calocitta, Neotropics, New World Jays, Biogeography, Taxonomy. 
Resumen. Se estudiaron las relaciones filogenéticas en los géneros Cyanocorax, Psilorhinus y Calocitta (Aves: Corvidae), un grupo diverso de urracas del Nuevo Mundo cuyas especies se distribuyen desde el sur de los Estados Unidos hasta Argentina. Aunque la ecología y el comportamiento de algunas especies en el grupo han sido estudiadas extensamente, la falta de una filogenia molecular ha impedido la interpretación rigurosa de estos estudios en un marco evolutivo. Dadas las diversas combinaciones de coloración de plumaje, tamaño y morfología presentes en las especies del grupo, su taxonomía ha sido inconsistente y la interpretación de sus patrones biogeográficos ha sido problemática. Mas aún, la similitud de plumaje en especies que están geográficamente distantes, como Cyanocorax dickeyi del oeste de Mexico y C. mystacalis del oeste de Ecuador y Perú, ha sido difícil de interpretar. Se presenta una filogenia para todas las especies en los tres géneros, basada en el estudio de dos genes nucleares y dos genes mitocondriales. Los árboles filogenéticos mostraron la parafilia de Cyanocorax y la división de todas las especies en dos grupos: "Clado A" en el cual se encuentran Psilorhinus morio, ambas especies Calocitta, Cyanocorax violaceus, C. caeruleus, C. cristatellus, y C. cyanomelas, y “Clado B" en el cual se encuentran el resto de las especies de Cyanocorax. Las relaciones entre especies del Clado A fueron ambiguas y, en general, poco resueltas. En el Clado B, los análisis mostraron la monofilia de las especies en "Cissilopha", pero no indicaron la monofilia de $C$. mystacalis $+C$. dickeyi. La complejidad filogenética de los linajes en el grupo sugiere varias complicaciones en el entendimiento de su biogeografía y taxonomía. Con base en los resultados filogenéticos se reconoce un solo género, Cyanocorax, con Psilorhinus y Calocitta como sinónimos. 


\section{Introduction}

Species in the genus Cyanocorax and allied genera Psilorhinus and Calocitta, constitute a morphologically, ecologically, and behaviorally diverse group of New World jays (NWJs), distributed from the extreme southern United States south to Argentina. Some species in the group have been studied extensively in terms of their social behavior (e.g., Crossin, 1967; Hardy, 1974; Raitt and Hardy, 1976, 1979; Langen, 1996; Williams and Hale, 2006), delayed soft-part color development (Hardy, 1973; Peterson, 1991), vocal repertoire (Hardy, 1961, 1979), and habitat preferences (e.g., Hardy, 1969; Raitt and Hardy, 1979; Amaral and Macedo, 2006). However, the lack of a robust hypothesis of relationships, as well as the paucity of detailed natural history studies for most South American species, has precluded rigorous interpretation of these characteristics in an evolutionary framework.

In addition to implications for understanding the evolution of the group, resolution of relationships among Cyanocorax species poses interesting systematic challenges. Owing to the diverse combinations of plumage coloration, size, and morphology found in Cyanocorax species, the genus has been described as “a pigeon-hole for a heterogeneous assemblage of jays” (Moore, 1935), apropos to the widely held perception that no characters support a coherent, natural group (e.g., Amadon, 1944; Goodwin, 1976). As a result, Cyanocorax has been subjected to several taxonomic overhauls involving large-scale splitting, lumping, and reallocation of taxa. 


\subsection{Taxonomic History}

Hellmayr (1934) presented the first comprehensive treatment of Cyanocorax and allied genera. He divided the current Cyanocorax into four genera: (1) Xanthoura, consisting solely of $X$. yncas, the only green-colored member of the group, distributed from southern Texas to northern Bolivia; (2) Cissilopha, consisting of four Mesoamerican jays-C. beecheii, C. sanblasiana, C. yucatanica, and C. melanocyanea — characterized by black heads and blue body plumage; (3) Uroleuca, represented by U. cristatellus, a distinctive species from central Brazil; and (4) Cyanocorax, containing one Mesoamerican-South American (C. affinis) and seven South American species (C. caeruleus, C. violaceus, C. heilprini, C. cayanus, C. chrysops [including $C$. cyanopogon], C. cyanomelas, and C. mystacalis). Also, he recognized two species in the (currently) monotypic genus Psilorhinus (P. morio and P. mexicanus), and one species of Calocitta, including the current C. formosa and C. colliei.

Based on subjective analysis of general morphology and plumage patterns, Amadon (1944) proposed a classification merging Xanthoura and Uroleuca into Cyanocorax, and placing Cissilopha into Cyanocitta, along with members of other NWJ genera (i.e., Cyanocitta, Cyanolyca, and Aphelocoma). He considered Psilorhinus and Calocitta as valid genera, and divided Cyanocorax into four "sections": (1) the "Coronideus" group, containing C. caeruleus, C. cyanomelas, and C. violaceus; (2) “Uroleuca”; (3) "Xanthoura”; and (4) a more restricted “Cyanocorax" including all other taxa, in addition to the newly described C. dickeyi (Moore, 1935). 
Blake and Vaurie (1962) divided the group in four genera: Cissilopha (sensu Helmayr, 1934), Cyanocorax (sensu Amadon, 1944), Calocitta, and Psilorhinus. Hardy (1969), in contrast, lumped all genera into a broad Cyanocorax with five subgenera: Calocitta, Psilorhinus, Cissilopha, Uroleuca, and Cyanocorax (including Xanthoura); also, he elevated Cyanocorax cyanopogon to a full species separate from C. chrysops (see also Meyer de Schauensee, 1966). Goodwin (1976) followed Blake and Vaurie (1962) in conferring generic status to Cissilopha, Psilorhinus, and Calocitta. Debates regarding the taxonomy of the group still continue. Whereas Monroe and Sibley (1993) and Madge and Burn (1994) recognized Cyanocorax (including Xanthoura, Uroleuca, and Cissilopha), Calocitta, and Psilorhinus (see also Bonaccorso and Peterson, 2007), others (AOU, 1983, 1998; Dickinson, 2003; Clements, 2007) recognized only Cyanocorax and Calocitta. In conclusion, the taxonomy of the group has been unstable, reflecting the lack of a robust hypothesis of relationships and insufficient morphological character variation on which to base a classification.

\subsection{The origin of the Tufted Jay, Cyanocorax dickeyi}

Within the Cyanocorax assemblage, morphologically similar species may have complex and discontinuous geographic distributions (Hardy, 1961; Goodwin, 1976). The most notorious example is the $\sim 4000 \mathrm{~km}$ gap existing between two morphologically similar species, $C$. dickeyi and C. mystacalis. Whereas C. dickeyi inhabits a minute area in the Pacific slope of the Sierra Madre Occidental of Mexico (Moore, 1935; Crossin, 1967), C. mystacalis is endemic to southwestern Ecuador and northwestern Peru (Ridgely and Tudor, 1989). To explain this biogeographic pattern, Amadon (1944) hypothesized that C. dickeyi was a relict of a more widely distributed ancestor that was out-competed by other Mesoamerican jays (see also Moore, 1935). 
Others have proposed that a flock of C. mystacalis was storm-blown from the Pacific coast of South America (in Hardy, 1969), or that $C$. dickeyi was a descendent of $C$. mystacalis brought to Mexico by Native Americans (Haemig, 1979). Given the close morphological similarity between the two species (see Hope, 1989), molecular studies are necessary to uncover their phylogenetic affinities.

\subsection{Phylogenetic Relationships}

The first phylogenetic treatment of Cyanocorax jays (Hope, 1989) was based on discrete and meristic osteological characters of 12 of the 16 species in Cyanocorax, in addition to Psilorhinus morio and Calocitta formosa. Major patterns recovered included "Cissilopha" as monophyletic (in 2 out of 3 analyses) and C. mystacalis and C. dickeyi as sister species; Psilorhinus was placed as sister to Calocitta or closely related to C. violaceus, C. caeruleus, and C. cyanomelas. The only clade supported by a discrete, unreversed synapomorphy was $C$. violaceus + C. caeruleus + C. cyanomelas (i.e., Amadon’s “Coronideus” group); relationships among other species were unstable and dependent on outgroup selection.

Molecular analyses of relationships among NWJs (Saunders and Edwards, 2000; Bonaccorso and Peterson, 2007) have supported the monophyly of Cyanocorax + Psilorhinus + Calocitta. However, because the most complete study considered only 6 of the 16 species of Cyanocorax, the question of the monophyly of the genus, as well as relationships among species, is unresolved. Herein, we expand the taxonomic sampling to include all species of Cyanocorax, in the context of other NWJ genera and a broad sampling of molecular markers, to provide a phylogenetic framework for understanding the evolution, systematics, and biogeography of the group. 


\section{Methods}

\subsection{Taxon and Gene Sampling}

We analyzed samples from 54 individuals, including all species in Cyanocorax and the allied genera Psilorhinus and Calocitta. For outgroup comparisons, we included representatives of all other NWJ genera (Cyanocitta cristata, Aphelocoma coerulescens, Gymnorhinus cyanocephalus, and Cyanolyca viridicyanus), which data were drawn from previous studies (Espinosa de los Monteros and Cracraft, 1997; Cicero and Johnson, 2001; Ericson et al., 2005; Bonaccorso and Peterson, 2007; Bonaccorso, 2009). Tissue samples for ingroup taxa were obtained through our sampling efforts (in Mexico, El Salvador, Guyana, Paraguay, and Argentina) via University of Kansas Natural History Museum general collecting expeditions, and from other museum collections in the U.S. (Table 1). Additionally, a subset of ingroup sequences was obtained from previous studies (Espinosa de los Monteros and Cracraft, 1997; Bonaccorso and Peterson, 2007; Bonaccorso, 2009).

The mitochondrial genes NADH dehydrogenase subunit 2 (ND2) and cytochrome $b$ (cytb) were analyzed as fast-evolving makers that could provide resolution at the tips of the tree. To obtain independent estimates of relationships, as well as information about deeper divergence, we sequenced three nuclear loci-Adenylate Kinase intron 5 (AK5), $\beta$-Fibrinogen intron 7 ( $\beta \mathrm{fb} 7$ ), and TGF $\beta 2.5$ - for representative individuals. Information on genes sequenced, GenBank accession numbers, catalog numbers, and associated locality data is summarized in Table 1.

List of tissue samples and GenBank accession numbers for sequences of species included in the present study. Acronyms: AMNH, American Museum of Natural History; ANSP, Academy of Natural Sciences; CUMZ, Cornell University Museum of Zoology; FMNH, Field Museum of Natural History; KUNHM, University of Kansas Natural History Museum; LSUMZ, Louisiana State University Museum of Zoology; MZFC, Museo de Zoología, Facultad de Ciencias, Universidad Nacional Autónoma de México; USMNH, National Museum of Natural History, Smithsonian Institution; YPM, Yale Peabody Museum. a'Sequences from Esponosa de los Monteros and Cracraft (1997); b sequences from Bonaccorso and Peterson (2007); ${ }^{c}$ sequences from Bonaccorso (2009). 


\begin{tabular}{|c|c|c|c|c|c|c|c|c|}
\hline Species & $\#$ & $\begin{array}{l}\text { Museum and } \\
\text { tissue number }\end{array}$ & Locality Information & ND2 & cytb & AK5 & Bfib7 & TGFß2.5 \\
\hline \multirow{5}{*}{$\begin{array}{l}\text { Cyanocorax } \\
\text { cayanus }\end{array}$} & 1 & KUNHM 5817 & Guyana: E. Barima River & DQ912614 & DQ912599 & DQ912631 & DQ912650 & GU144911 \\
\hline & 2 & KUNHM 5819 & Guvana: E Barima River & GU144811 & GU144854 & & & \\
\hline & 3 & AMNH ROP 252 & Venezuela: Bolivar, 40 km E Tumeremo & GU144812 & GU144855 & & & \\
\hline & 4 & LSUMZ 25552 & Brazil: Amapa & GU144813 & GU144856 & & & \\
\hline & 5 & FMNH 391652 & Brazil: Amapa & GU144814 & GU144857 & & & \\
\hline \multirow[t]{5}{*}{ C. cyanomelas } & 6 & KUNHM 134 & Paraguay: Concepción, San Luís & GU144815 & GU144858 & GU144898 & GU144904 & GU144912 \\
\hline & 7 & KUNHM 3171 & Paraguay: Alto Paraguay, Estancia Triunfo & GU144816 & GU144859 & & & \\
\hline & 8 & FMNH 324102 & Peru: Madre de Dios, Hacienda Amazonia & GU144817 & GU144860 & & & \\
\hline & 9 & FMNH 334725 & Bolivia: Santa Cruz, Chiquitos & GU144818 & GU144861 & & & \\
\hline & 10 & AMNH 2279 & Bolivia: Santa Cruz, Velazco, near El Tuna & GU144819 & GU144862 & & & \\
\hline \multirow[t]{5}{*}{ C. chrysops } & 13 & KUNHM 171 & Paraguay: Concepción, San Luís & DQ912609 & $\mathrm{U} 77334^{\mathrm{a}}$ & DQ912626 & DQ912646 & FJ59830 \\
\hline & 14 & KUNHM 3667 & $\begin{array}{l}\text { Paraguay: Itapua, San Rafael N.P., San } \\
\text { Pedro Mi }\end{array}$ & GU144820 & GU144863 & & & \\
\hline & 15 & AMNH 2249 & Bolivia: Santa Cruz, Comunidad Karapari & GU144821 & GU144864 & & & \\
\hline & 16 & CUMZ 52152 & Argentina: Jujuy & GU144822 & GU144865 & & & \\
\hline & 17 & LSUMZ 18785 & Bolivia: Santa Cruz & GU144823 & GU144866 & & & \\
\hline \multirow[t]{4}{*}{ C. affinis } & 18 & LSUMZ 28539 & Panama: Colón & GU144824 & GU144867 & & & \\
\hline & 19 & LSUMZ 28602 & Panama: Colón & GU144825 & GU144868 & & & \\
\hline & 20 & $\begin{array}{l}\text { USMNH BO } \\
1960\end{array}$ & $\begin{array}{l}\text { Panama: Bocas del Toro, } 4 \text { km W Chriquí } \\
\text { Grande }\end{array}$ & GU144826 & GU144869 & GU144899 & GU144905 & GU144913 \\
\hline & 21 & $\begin{array}{l}\text { USMNH BO } \\
1980\end{array}$ & $\begin{array}{l}\text { Panama: Bocas del Toro, } 4 \text { km W Chriquí } \\
\text { Grande }\end{array}$ & GU144827 & GU144870 & & & \\
\hline \multirow[t]{4}{*}{ C. mystacalis } & 22 & ASNP 1813 & $\begin{array}{l}\text { Ecuador: Loja, SE Celica, along Río } \\
\text { Catamayo }\end{array}$ & GU144828 & GU144871 & & & \\
\hline & 24 & ASNP 4153 & Ecuador: Loja, 4 km N of Zapotillo & GU144829 & GU144872 & & & \\
\hline & 25 & ASNP 4596 & Ecuador: Loja, 10 km E Mangahurcu & GU144830 & GU144873 & & & \\
\hline & 26 & LSUMZ 5160 & Peru: Lambayeque & GU144831 & GU144874 & GU1448900 & GU144906 & GU144914 \\
\hline C. heilprini & & LSUMZ 48619 & Brazil: Amazonas, Rio Uaupés, Jauareté & GU144832 & GU144875 & & & \\
\hline \multirow[t]{2}{*}{ C. cyanopogon } & 27 & FMNH 392998 & Brazil: Alagoas, Pirañas, Fazenda Mecejana & GU144833 & GU144876 & & & \\
\hline & 28 & FMNH 392999 & Brazil: Alagoas, Pirañas, Fazenda Mecejana & GU144834 & GU144877 & GU144901 & GU144907 & GU144915 \\
\hline C. caeruleus & & YPM 80868 & Brasil: Sao Paulo, Riberao Onca Parda & GU144835 & GU144878 & & & \\
\hline \multirow[t]{4}{*}{ C. violaceus } & 29 & FMNH 324104 & Peru: Madre de Dios, Hacienda Amazonia & GU144836 & GU144879 & GU144902 & GU144908 & GU144916 \\
\hline & 30 & FMNH 398598 & Peru: Madre de Dios, 2.75 km E Shintuya & - & GU144880 & & & \\
\hline & 31 & ANSP 5697 & $\begin{array}{l}\text { Ecuador: Sucumbíos, Ca. } 14 \text { km N Tigre } \\
\text { Playa }\end{array}$ & GU144837 & GU144881 & & & \\
\hline & 32 & ANSP 5940 & $\begin{array}{l}\text { Ecuador: Sucumbíos, Ca. } 20 \text { km NE } \\
\text { Lumbaqui }\end{array}$ & GU144838 & GU144882 & & & \\
\hline \multirow[t]{3}{*}{ C. cristatellus } & 33 & LSUMZ 13888 & Bolivia: Santa Cruz & GU144839 & GU144883 & GU144903 & GU144909 & GU144917 \\
\hline & $33 b$ & LSUMZ 13889 & Bolivia: Santa Cruz & GU144840 & GU144884 & & & \\
\hline & $33 c$ & LSUMZ 13915 & Bolivia: Santa Cruz & GU144841 & GU144885 & & & \\
\hline \multirow[t]{3}{*}{ C. dickeyi } & $33 s$ & MZFC 15315 & Mexico: Sinaloa & DQ912611 & DQ912596 ${ }^{\mathrm{b}}$ & DQ912628 & DQ912647 ${ }^{\mathrm{b}}$ & GU144918 \\
\hline & $34 s$ & MZFC 15666 & Mexico: Sinaloa & GU144842 & GU144886 & & & \\
\hline & $40 \mathrm{~s}$ & MZFC 15316 & Mexico: Sinaloa & GU144843 & GU144887 & & & \\
\hline \multirow[t]{5}{*}{ C. yncas } & 35 & LSUMZ 30899 & USA: Texas & GU144844 & GU144888 & & & \\
\hline & 36 & LSUMZ 43650 & Peru: San Martín & GU144845 & GU144889 & & & \\
\hline & 37 & LSUMZ 6114 & Ecuador: Morona-Santiago & GU144846 & GU144890 & & & \\
\hline & 39 & MZFC 15927 & $\begin{array}{l}\text { Mexico: San Luís Potosí, San Nicolás de } \\
\text { los Montes }\end{array}$ & GU144847 & GU144891 & & & \\
\hline & 40 & MZFC 15722 & Mexico: Querétaro, Laguna de la Cruz & DQ912610 & DQ912595 & DQ912627 & GU144910 & GU144919 \\
\hline \multirow[t]{2}{*}{ C. yucatanicus } & 41 & MZFC 14340 & Mexico: Campeche, 9 km W Tenabo & GU144848 & GU144892 & & & \\
\hline & 42 & MZFC B1661 & Mexico: Yucatán & DQ912613 & DQ912598 & DQ912630 & DQ912649 & GU144920 \\
\hline \multirow[t]{2}{*}{ C. sanblasianus } & 1 & KUNHM 106859 & Mexico: Nayarit, 9 mi E Las Varas & GU144849 & GU144893 & & & \\
\hline & 2 & KUNHM 106860 & Mexico: Guerrero, El Arenal & GU144850 & GU144894 & & & \\
\hline \multirow[t]{2}{*}{ C. beecheii } & 1 & KUNHM 101842 & Mexico: Nayarit & GU144851 & GU144895 & & & \\
\hline & 2 & MZFC 20513 & Mexico: Sinaloa & GU144852 & GU144896 & & & \\
\hline \multirow[t]{2}{*}{ C. melanocyaneus } & 43 & KUNHM 7657 & El Salvador: San Vicente & DQ912612 & DQ912597 & DQ912629 & DQ912648 & GU144921 \\
\hline & 44 & KUNHM 4998 & El Salvador: Morazán & GU144853 & GU144897 & & & \\
\hline \multirow[t]{2}{*}{ Psilorhinus morio } & 45 & KUNHM B1896 & Mexico: Campeche & DQ912607 & DQ912593 & DQ912624 & DQ912645 & FJ598304 ${ }^{\mathrm{C}}$ \\
\hline & 46 & KUNHM B2169 & Mexico: Campeche & DQ912608 & DQ912594 & & & \\
\hline Calocitta formosa & 47 & KUNHM 9352 & El Salvador: Usulután & DQ912602 & $\mathrm{U} 77336^{\mathrm{a}}$ & DQ912620 & DQ912639 & FJ598302 ${ }^{C}$ \\
\hline C. colliei & 48 & FMNH 343602 & Mexico: Sinaloa & DQ912603 ${ }^{b}$ & DQ912591 & & & \\
\hline
\end{tabular}




\subsection{DNA Amplification and Sequencing}

Genomic DNA was extracted from frozen tissue using salt precipitation protocols (M. Fujita, unpubl.). Amplification was carried out using the following primers: L5143 or L5216, and H6313 (Sorenson et al., 1999) for ND2; L14990 (Kocher et al., 1989) and H16065 (Tim Birt, unpubl.) for cytb; FIB-B17U and FIB-B17L (Prychitko and Moore, 1997) for $\beta \mathrm{fb} 7$; AK5b+ and AK6c- (Shapiro and Dumbacher, 2001) for AK5; and TGFb2.5F and TGFb2.6R for TGFb2.5 (Sorenson et al., 2004). DNA extracts from Cyanocorax sanblasianus, C. beecheii (sample 1, Table 1), C. heilprini, and C. caeruleus were obtained from museum skin samples in a dedicated ancient DNA laboratory (Fleischer et al., 2000, 2001); DNA extracts from an additional degraded tissue sample of $C$. beecheii (sample 2, Table 1) were obtained using the DNeasyTissue extraction kit (Qiagen Inc.). Amplification from skin-extracted DNA was carried out using several internal primers (Appendix I), which allowed amplifying and sequencing of short DNA fragments (150-350 bp). In all ancient DNA work, independent laboratory facilities were used to separate pre- and post-PCR manipulations, and special care (e.g., multiple controls, use of fresh lab supplies) was taken to reduce risk of contamination.

We used a standard PCR protocol (Bonaccorso and Peterson, 2007) for mitochondrial genes, and a touchdown protocol for nuclear genes (i.e., an initial denaturation of $94^{\circ} \mathrm{C} / 3 \mathrm{~min} ; 5$ cycles of $94^{\circ} \mathrm{C} / 30 \mathrm{sec}, 60^{\circ} \mathrm{C} / 30 \mathrm{sec}, 72^{\circ} \mathrm{C} / 40 \mathrm{sec} ; 5$ cycles of $94^{\circ} \mathrm{C} / 30 \mathrm{sec}, 56^{\circ} \mathrm{C} / 30 \mathrm{sec}, 72^{\circ} \mathrm{C} / 40$; 35 cycles of $96^{\circ} \mathrm{C} / 30 \mathrm{sec}, 52^{\circ} \mathrm{C} / 30 \mathrm{sec}, 72^{\circ} \mathrm{C} / 40 \mathrm{sec}$; and a final extension of $72^{\circ} \mathrm{C} / 10 \mathrm{~min}$; $\mathrm{R}$. Moyle, pers. comm.). Amplification products were treated with ExoSAP-IT (Affymetrix) to degrade unincorporated primers and dNTP's. Cycle sequencing was completed with the corresponding PCR primers and BigDye Terminator 3.1 chemistry (Applied Biosystems). Sequencing reaction products were purified with CleanSEQ magnetic beads (Agencourt) and 
resolved in an ABI Prism 3100 Genetic Analyzer (Applied Biosystems). Data from heavy and light strands were assembled to obtain a consensus sequence for each sample using Sequencher 4.1 (Gene Codes Corp., 2000). Nucleotide sequences were aligned in CLUSTAL X using default settings (Thompson et al., 1997). MacClade ver. 4.0 (Maddison and Maddison, 2000) was used to adjust alignments by eye and to translate nucleotide sequences into amino acids.

\subsection{Sequence Aligning and Phylogenetic Analyses}

Best-fit models of molecular evolution were selected in MODELTEST v.3.7 (Posada and Crandall, 1998, 2001) under the Akaike Information Criterion (AIC) for each gene and codon position (i.e., ND2, cytb), and for combined datasets (see below). Model parameters estimated from MODELTEST were used in subsequent model-based analyses.

Individual gene trees were estimated using maximum parsimony (MP), and maximum likelihood (ML) analyses. Tree topology and clade support were used as gross measures of congruence in phylogenetic signal (Bull et al., 1993; de Queiroz et al., 1995; Wiens, 1998); “strong” incongruence was identified by the presence of conflicting nodes showing $\geq 70 \%$ non parametric bootstrap support. To explore potential sources of conflict among genes, sequence data were tested for stationarity in base frequencies $\left(\chi^{2}\right.$ test of homogeneity in PAUP* v.4.0b10 [Swofford, 2002]) and rate homogeneity among lineages, via a likelihood ratio test (Felsenstein, 1981), by comparing the likelihood scores of the ML trees with and without the molecular clock enforced. After preliminary examination of individual gene trees, we performed combined analyses to amplify potentially congruent signals, but questioned weakly supported nodes that reflected conflicting signals (Wiens, 1998). Combined mitochondrial and mitochondrial + nuclear trees were estimated, using MP, ML, and Bayesian analyses. Mitochondrial analyses 
were performed over all available samples; individual nuclear-gene and mitochondrial + nuclear analyses included one sample for each species, with exception of Cyanocorax heilprini, C. sanblasianus, C. beecheii, C. caeruleus, and Calocitta colliei.

Parsimony analyses were performed treating gaps as missing data, and heterozygous positions (in nuclear genes) as polymorphisms. Trees were obtained through heuristic searches in PAUP with 10,000 stepwise random additions (TBR branch-swapping). Clade support was estimated via heuristic searches with 1000 bootstrap pseudoreplicates (Felsenstein, 1985), each pseudoreplicate consisting of 100 stepwise random additions.

Maximum likelihood trees were estimated using GARLI (Genetic Algorithm for Rapid Likelihood Inference, ver. 0.951; Zwickl, 2006), which estimates tree topology, branch lengths, and model parameters that maximize the -ln likelihood, in a simultaneous approach. Analyses were conducted specifying the model "family" obtained by MODELTEST, but allowing the program to estimate parameter values from the data. For each dataset, $\geq 10$ independent analyses were run to assure that they produced consistent likelihood scores. Bootstrap support was assessed via 100 and 1000 pseudoreplicates for the individual-gene and the combined datasets, respectively; bootstrap searches were performed under the same settings used in tree search.

Bayesian analyses of the combined datasets were performed in MrBayes 3.1 (Ronquist and Huelsenbeck, 2003), implementing partitions by gene and by codon position (ND2 and cytb), and assigning to each partition its best-fit model family of nucleotide substitution. All parameters were unlinked between partitions (except topology and branch lengths), and rate variation $($ prset ratepr $=$ variable) was invoked. Analyses consisted of four independent runs of 5 $\times 10^{6}$ generations and 10 Markov chains (temperature $=0.20$ ), with trees sampled every 1000 generations. Stationarity was assessed by plotting -lnL per generation in Tracer 1.3 (Rambaut 
and Drummond, 2004) and plotting posterior probabilities of clades as a function of number of generations in AWTY (Wilgenbusch et al., 2004). Comparison of performance of multiple runs allowed selection of those runs that converged to the highest likelihood values and reflected stability in the posterior probabilities of clades. All four runs fulfilled these conditions and reached stationarity after 500,000 generations. From the 5000 resulting trees per run, the first 1000 were discarded as “burn in.” The remaining 16,000 trees were combined to calculate posterior probabilities in a 50\% majority-rule consensus tree.

\subsection{Hypothesis Testing}

Statistical comparison between the ML tree and a ML tree resulting from enforcing the monophyly of the genus Cyanocorax and the monophyly of C. mystacalis $+C$. dickeyi was conducted via the likelihood-ratio test of monophyly (Huelsenbeck et al., 1996a). This test compares the likelihood between the best ML topology $\left(\mathrm{T}_{1}\right)$ and that showing the monophyly of the group of interest $\left(\mathrm{T}_{0}\right)$. Significance of likelihood difference $(\delta)$ is assessed by comparing it to a null distribution obtained via parametric bootstrapping (Effron, 1985; Felsenstein, 1988; Huelsenbeck et al., 1996b); in short, replicated datasets are created by simulation under the model and model parameter values estimated from the original data optimized over the null topology. Then, two different ML searches are conducted for each simulated dataset to estimate the likelihood of (1) the ML tree and (2) the ML tree with the null topology enforced. Calculation of likelihood difference between trees produced by (1) and (2) provides the null distribution for assessing whether $\delta$ deviates from random expectations. Given that two independent tests were performed (monophyly of Cyanocorax and monophyly of C. mystacalis + 
C. dickeyi), significance of $\delta$-values was assessed after adjusting the $P$ level using a Bonferroni correction (Sokal and Rohlf, 1995).

To avoid potential problems related to missing data (e.g., distortion of branch lengths), parametric bootstrapping was implemented over the mitochondrial + nuclear, pruned dataset. A total of 100 matrices was simulated for each test (i.e., monophyly of Cyanocorax and of $C$. mystacalis + C. dickeyi) with Batch Architect (Maddison and Maddison, 2004a) in Mesquite 1.05 (Maddison and Maddison, 2004b). We used GARLI for conducting all ML searches (i.e., ML trees and ML “constrained” trees, on real and simulated datasets).

\section{Results}

\subsection{Sequence Attributes and Model Selection}

For all well-preserved tissues (except Cyanocorax violaceus sample 30 and $C$. cyanomelas sample 10), we obtained 1002 bp of ND2 and 999 bp of cytb. Use of internal primers allowed amplification and sequencing of samples for which preserved tissues were not available. Species and numbers of base-pairs sequenced from such samples are as follows: $C$. heilprini (1002 bp for ND2, 486 bp for cytb), C. beecheii 1 (675 bp for ND2, 411 bp for cytb), C. beecheii 2 (676 bp for ND2, 979 bp for cytb) C. caeruleus (960 bp for ND2, 486 bp for cytb), C. sanblasianus 1 (1002 bp for ND2, 411 bp for cytb) and C. sanblasianus 2 (867 bp for ND2, 411 bp for cytb). Maximum Likelihood-corrected pair-wise distances based on cytb sequences are

provided in Appendix II. Among nuclear introns, apart from specific length variation observed in outgroup sequences, indels were limited to 1-16 base pairs, allowing unambiguous alignment in all cases. 
Variable/parsimony-informative positions across genes were distributed as follows: 457/375 out of 1002 for ND2, 394/311 out of 999 for cytb, 77/15 out of 518 for AK5, 99/33 out of 856 for $\beta \mathrm{fb} 7$, and 53/18 out of 564 for TGF $\beta 2.5$. According to the AIC, MODELTEST selected models nested within the GTR + I $+\Gamma$ model "family" for all but one data partition (HKY $+\Gamma$ was selected for cytb second-codon positions), and for the individual mitochondrial genes and combined mitochondrial and mitochondrial + nuclear datasets. The best-fit model families for the nuclear genes were HKY $+\Gamma$ for AK5, and GTR $+\Gamma$ f $\mathrm{ffb} 7$ and TGF $\beta 2.5$. Model parameter values estimated via ML analysis of individual genes, are summarized in Table 2. Nucleotide composition bias across lineages, considering codon positions (mitochondrial genes) and complete gene fragments, was non-significant in all cases $(P>0.05)$, and the assumption of a molecular-clock mode of evolution was not rejected for any loci $(P>0.05)$.

Table 2. Summary of nucleotide substitution models, model parameters, and tree scores estimated from maximum likelihood trees.

\begin{tabular}{|c|c|c|c|c|c|c|c|c|c|c|c|c|}
\hline \multicolumn{5}{|c|}{ Base frequencies } & \multicolumn{5}{|c|}{ Rate matrix } & \multirow[b]{2}{*}{$\alpha$} & \multirow[b]{2}{*}{ Pinv } & \multirow[b]{2}{*}{$-\ln 1$} \\
\hline Gene & $\mathrm{A}$ & $\mathrm{C}$ & $\mathrm{G}$ & $\mathrm{T}$ & $\mathrm{AC}$ & $\mathrm{AG}$ & AT & $\mathrm{CG}$ & $\mathrm{CT}$ & & & \\
\hline ND2 & 0.330 & 0.348 & 0.087 & 0.236 & 0.880 & 23.122 & 0.669 & 0.657 & 11.500 & 1.146 & 0.466 & -8645.9573 \\
\hline cytb & 0.309 & 0.368 & 0.120 & 0.204 & 0.953 & 10.132 & 1.082 & 0.257 & 15.627 & 1.482 & 0.553 & -7973.7999 \\
\hline Mitochondrial & 0.321 & 0.346 & 0.102 & 0.231 & 0.900 & 17.619 & 0.547 & 0.372 & 12.417 & 0.208 & 0.011 & -13124.2970 \\
\hline AK5 & 0.217 & 0.303 & 0.306 & 0.175 & \multicolumn{5}{|c|}{ Transition/transversion ratio $=3.460$} & 0.426 & N/A & -1170.3705 \\
\hline$\beta \mathrm{fb} 7$ & 0.322 & 0.176 & 0.186 & 0.316 & 1.567 & 0.785 & 2.982 & 7.160 & 0.654 & 0.475 & N/A & -1886.9103 \\
\hline TGF $\beta 2.5$ & 0.243 & 0.244 & 0.211 & 0.302 & 0.779 & 7.706 & 0.633 & 1.142 & 4.440 & 0.375 & N/A & -1176.6071 \\
\hline $\begin{array}{l}\text { Mitochondrial + } \\
\text { nuclear } \\
\text { (total evidence) }\end{array}$ & 0.299 & 0.291 & 0.164 & 0.247 & 1.387 & 12.679 & 0.732 & 0.429 & 15.877 & 0.331 & 0.490 & -16981.317 \\
\hline $\begin{array}{l}\text { Mitochondrial + } \\
\text { nuclear (pruned) }\end{array}$ & 0.296 & 0.286 & 0.166 & 0.251 & 1.711 & 12.358 & 0.919 & 0.592 & 18.617 & 0.311 & 0.481 & -14682.317 \\
\hline
\end{tabular}

\subsection{Phylogenetic Analyses}

Individual MP and ML analyses of ND2 and cytb revealed general congruence in phylogenetic signal (not shown). Although specific details of relationships differ among genes and among analyses, no strong conflicts in topology were encountered; thus, we combined both genes in a single mitochondrial dataset. Figure 1 shows the Bayesian tree of the mitochondrial dataset, including Bayesian posterior probabilities and ML bootstrap support. The topology of 
the MP 50\% majority rule consensus tree based on the mitochondrial dataset (24 equally

parsimonious trees, 2306 steps; consistency index $=0.439$, rescaled consistency index $=0.350$;

not shown) was in general agreement with those of ML and BA, unless otherwise specified.

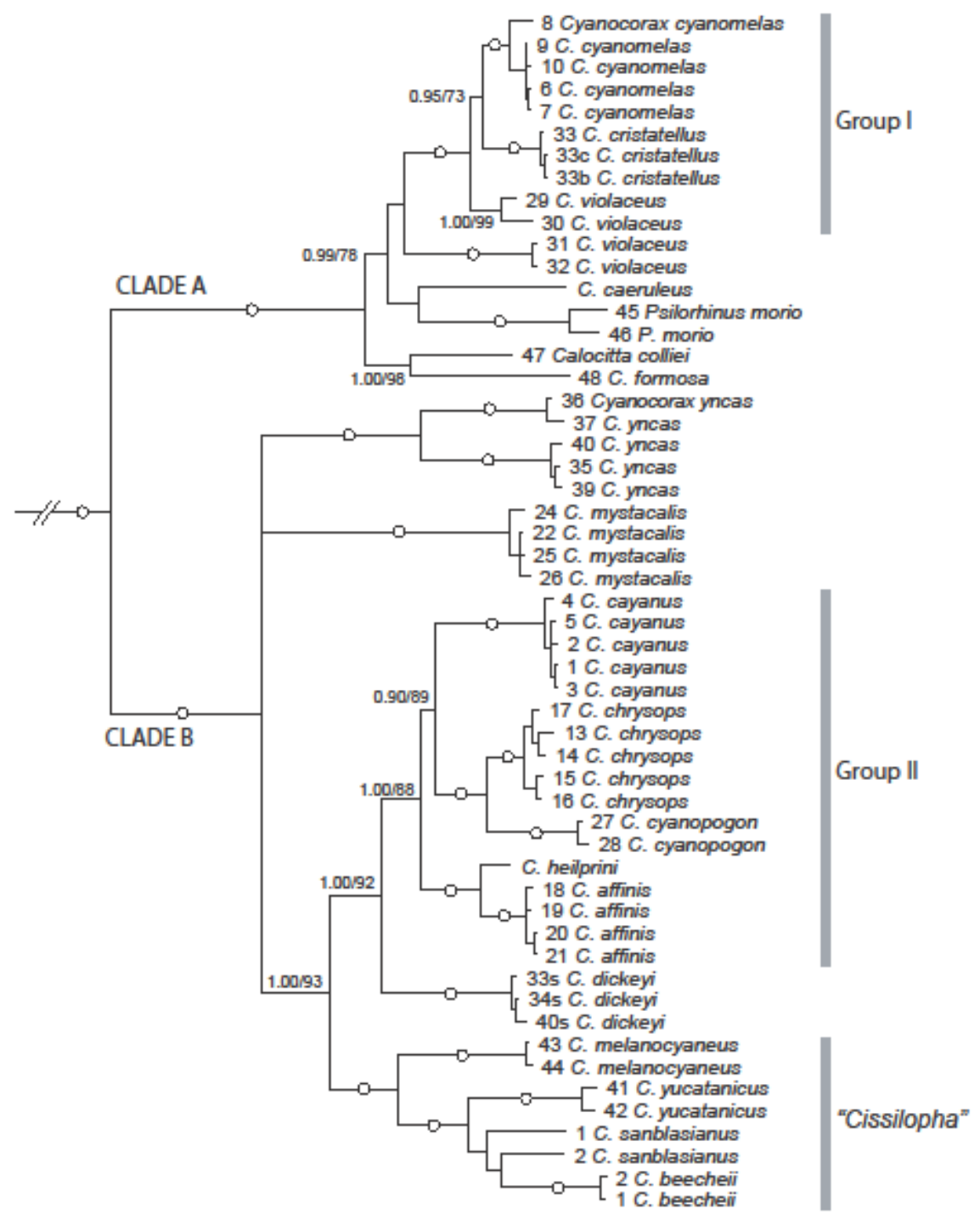

$\overline{0.01}$ substitutions/site

01.00 Bayesian posterior probability and $100 \%$ ML bootstrap value

FIG. 1 
Fig. 1. Bayesian 50\% majority rule consensus tree estimated from the mitochondrial dataset (ND2 and cytb; 2001 bp). Bayesian posterior probabilities/maximum likelihood bootstrap values (below branches) are indicated whenever nodes were recovered with less than 1.00 posterior probability or $100 \%$ bootstrap support.

Analyses of the mitochondrial dataset (Fig. 1) recovered Cyanocorax + Psilorhinus + Calocitta as monophyletic, and show a further division into two main clades: Clade A, containing Calocitta, Psilorhinus, Cyanocorax violaceus, C. caeruleus, C. cristatellus, and C. cyanomelas; and Clade B, including the remaining species of Cyanocorax. Within Clade A, Calocitta was sister to a group containing all other species (0.99 Bayesian posterior probabilities, 78\% ML bootstrap support, Fig. 1), but this relationship was not recovered by the MP 50\% majority rule consensus tree (not shown). All other lineages in Clade A are represented by a virtual polytomy among Psilorhinus morio, C. caeruleus, C. violaceus from Ecuador, and a strongly supported clade (“Group I”) formed by C. violaceus from Peru + (C. cristatellus + C. cyanomelas), which renders $C$. violaceus paraphyletic. Nonetheless, different, weakly supported topologies were obtained from individual-gene (ND2 and cytb) trees, with the positions of Psilorhinus, Cyanocorax caeruleus, and C. violaceus from Ecuador being unstable across analyses. These discrepancies reflected in low support for nodes within Clade A, except for that uniting Group I (1.00 Bayesian posterior probabilities, 100\% ML and MP bootstrap support). Relationships within Clade B are represented by another polytomy among C. yncas, $C$. mystacalis, and a well-supported clade containing "Cissilopha” jays + all other Cyanocorax species. Within “Cissilopha,” C. sanblasianus was recovered as paraphyletic with respect to C. beecheii, although the node uniting both species showed low support. The sister clade of "Cissilopha” is C. dickeyi + "Group II", whereas in "Group II", C. affinis + C. heilprini is sister to C. cayanus (C. chrysops + C. cyanopogon). Relationships within Clade B were consistent among MP, ML, and Bayesian analyses of the mitochondrial dataset, with two exceptions. Maximum Likelihood and MP analyses showed C. mystacalis and C. yncas as monophyletic and 
sister to all other species (56\% ML and 60\% MP bootstrap support), and MP did not recover the node of $C$. sanblasianus $+C$. beecheii.

In general, individual analyses of the three nuclear introns were less informative regarding relationships within Cyanocorax (Fig. 2). AK5 recovered Clade A with high bootstrap support. $\beta \mathrm{fb} 7$ supported the monophyly of the Cyanocorax, Calocitta, Psilorhinus assemblage, the monophyly of species in Clade A, and a sister relationship between Psilorhinus and Calocitta; other relationships disagree with those resulting from the mitochondrial analyses, but showed low bootstrap support. TGF $\beta 2.5$ provided the most information, supporting the monophyly of the whole assemblage, Clades A and B, and Calocitta + Psilorhinus.

AK5

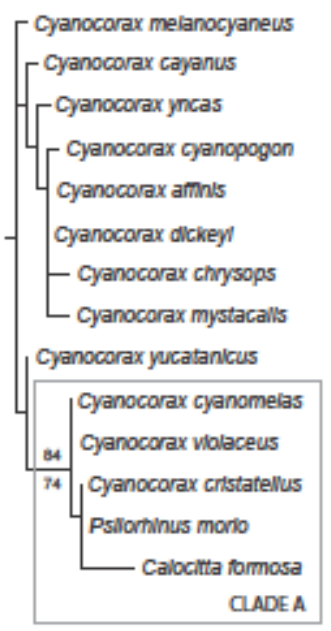

Bfb7

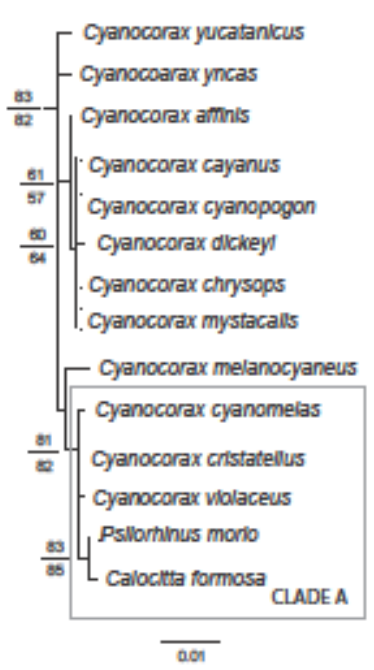

TGF 32.5

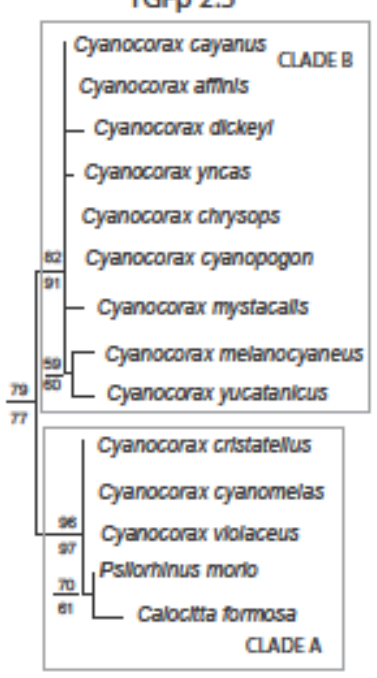

FIG. 2

Fig 2. Maximum likelihood (ML) trees estimated for the individual nuclear genes (AK5, $\beta$ fib7, and TGF $\beta 2.5$ ). Values on nodes indicate maximum likelihood (above) and maximum parsimony (below) bootstrap support.

Analyses of the combined mitochondrial + nuclear dataset produced similar topologies to those obtained from the mitochondrial dataset. However, the position of C. mystacalis, C. yncas, 
Psilorhinus, and Calocitta remained unstable or conflicting between ML and Bayesian analyses

(Fig. 3). The MP analysis of the mitochondrial + nuclear dataset produced one most parsimonious tree (1974 steps, $\mathrm{CI}=0.5329, \mathrm{RC}=0.2879$; not shown), which resulted in the same general topology of the Bayesian and ML trees, with two exceptions: it reconstructed the same relationships as the Bayesian tree with respect to the position of $C$. yncas and $C$.

mystacalis, and the same relationships as the ML tree with respect to Psilorhinus and Calocitta (MP bootstrap supports $<50 \%$ in both cases).

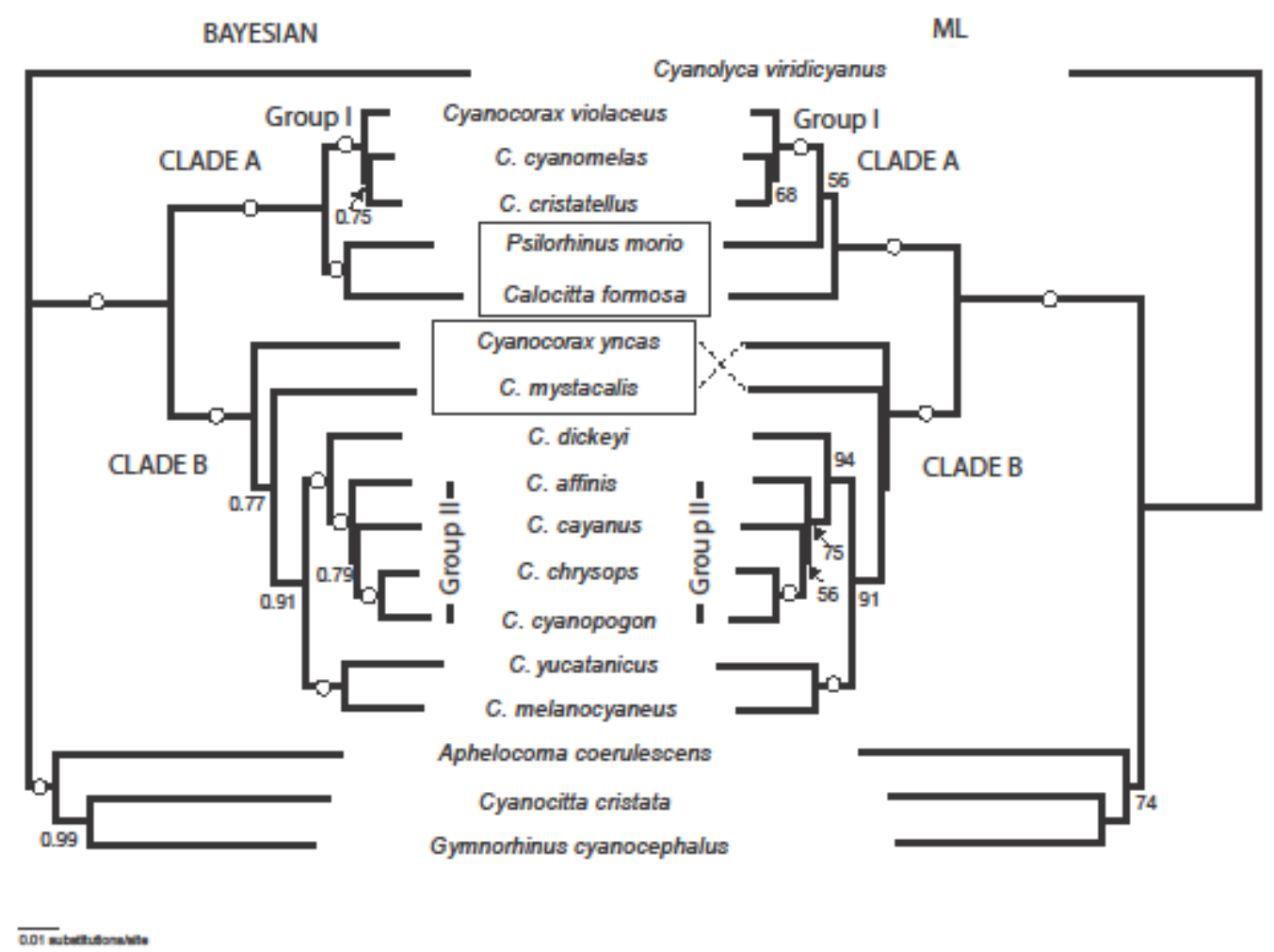

FIG. 3

Fig. 3. Bayesian $50 \%$ majority rule consensus tree (left) and maximum likelihood tree estimated from the total evidence dataset (ND2, cytb, AK5, $\beta \mathrm{fb} 7$, and TGF $\beta 2.5$; $4077 \mathrm{bp}$ ). Bayesian posterior probabilities and maximum likelihood bootstrap values are indicated in each case.

\subsection{Hypothesis Testing}


According to the parametric bootstrapping tests, the null hypotheses of monophyly of Cyanocorax and of that of a sister relationship between C. mystacalis and C. dickeyi were rejected with high significance. In testing the monophyly of Cyanocorax, the difference between the ML tree and the constraint ML tree drawn from the real dataset $(-\ln$ likelihood $=15669.408$ vs. $15729.410 ; \delta=60.002$ ln units) was significantly different from $\delta$ values obtained by simulation $(P<0.05)$. Therefore, Calocitta and Psilorhinus must be considered integral components of the Cyanocorax radiation. Also, the difference between the ML tree and the constraint ML tree enforcing the monophyly of C. mystacalis + C. dickeyi, was significant (-ln likelihood $=15669.408$ vs. $15688.984 ; \delta=19.576 \ln$ units; $P<0.05$ ); then, according to this analysis, they should not be considered as sister species.

\section{Discussion}

\subsection{Phylogeny of Cyanocorax}

Phylogenetic trees based on mitochondrial and nuclear genes, as well as on different analyses, produced a basic structure for species-level relationships within Cyanocorax and allied genera (Figs. 1-3). The most important result is the paraphyly of Cyanocorax with respect to Psilorhinus and Calocitta; this hypothesis is supported statistically by the parametric bootstrapping test, rejecting the monophyly of the current concept of Cyanocorax. A second major result is the division of all species into two well-supported groups, Clades A and B: Clade A containing Psilorhinus, Calocitta, Cyanocorax caeruleus, C. violaceus, C. cyanomelas, C. cristatellus, and C. violaceus; and Clade B containing the "Cissilopha" jays and the remaining species of Cyanocorax. 
Phylogenetic Relationships within Clade A.-Relationships within this clade were particularly unstable with respect to the position of Psilorhinus morio. This species was placed as sister to $C$. caeruleus based on combined mitochondrial analyses, but as sister to Calocitta in analyses of independent nuclear loci ( $\beta \mathrm{fb} 7$ and TGF $\beta 2.5$, Fig. 2) and the Bayesian analysis of the combined mitochondrial + nuclear dataset (Fig. 3). Similar difficulties were encountered by Hope (1989), whose analyses showed Psilorhinus as sister to Calocitta, or to C. violaceus + C. caeruleus + C. cyanomelas, depending on outgroup selection.

Ambiguity and uncertainty on the positions of Calocitta, Psilorhinus, Cyanocorax caeruleus, and C. violaceus from Ecuador contrast with the high support obtained for Group I (C. cyanomelas, C. cristatellus, and C. violaceus from Peru) in all analyses. Common ancestry of $C$. cyanomelas, C. violaceus, and C. caeruleus was expected based on plumage similarity (i.e., the “Coronideus”group; Amadon, 1944), as well as two osteological synapomorphies (one unreversed, another present also independently in Cyanolyca; Hope, 1989). However, in our phylogeny, C. cristatellus (not C. caeruleus) is closely related to C. cyanomelas and C. violaceus from Peru. Because C. cristatellus was not analyzed by Hope (1989), it is not possible to assess whether its molecular affinities with $C$. violaceus and $C$. cyanomelas coincide with osteological synapomorphies. In any case, the phylogenetic positions of both C. caeruleus and C. violaceus from Ecuador are in conflict with previous assessments of relationships based on morphology. With regard to the paraphyly of $C$. violaceus, examination of study skins from Ecuador did not reveal marked differences from those from Peru, other than slight color variation (N. Rice, pers. comm.). Given the relatively long and well-supported branch leading to Group I (C. violaceus from Peru + C. cyanomelas + C. cristatellus), it is improbable that this structure is caused by stochastic phylogenetic error (Funk and Omland, 2003). Moreover, it does not seem 
plausible that this structure is the result of amplification of nuclear pseudogenes, because our independently obtained sequences of ND2 and cytb provide the same signal, and it is unlikely that sequences obtained in both cases come from nuclear pseudogenes. Alternate explanations include that samples from Ecuador (1) represent a cryptic species north of the Amazon River or (2) carry ancestrally polymorphic mitochondrial haplotypes. It seems clear at this point that answering either question may require extensive sampling of populations of $C$. violaceus and closely related species across their ranges, as well as incorporation of faster-evolving nuclear markers.

Phylogenetic Relationships within Clade B.-In general, phylogenetic structure within Clade B was stable across analyses, although the positions of Cyanocorax mystacalis and C. yncas were ambiguous. Regardless of its position in the tree, C. yncas sequences separated into distinct groups corresponding the disjunct North and South American portions of the range of the species (Fig. 4). Differences in plumage, habitat preferences (e.g., Meyer de Shauensee, 1966; Goodwin, 1976), social behavior (Alvarez, 1975; Gayou, 1986), and vocalizations suggest that these populations might represent distinct species (Ridgely and Greenfield, 2001; Hilty, 2003): C. yncas (from northern Colombia and Venezuela to northern Bolivia) and C. luxuosus (from Texas to northern Honduras). Further analysis of populations from across the range of the species, particularly in Central America and northern South America, will be crucial in assessing their validity as independent evolutionary lineages (Wiley, 1978). 


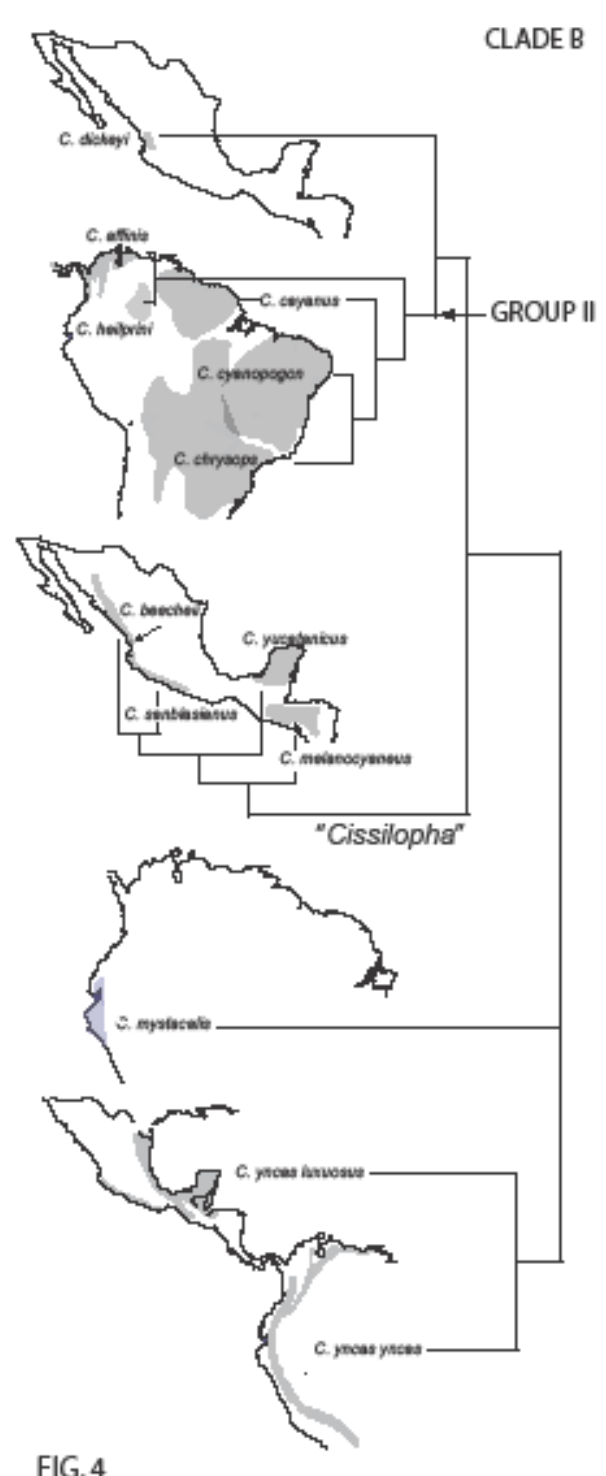

Fig. 4. Geographic distribution and phylogenetic relationships among species in Clade B (tree topology from Fig. 1). Darker shades (and arrow in the case of Cyanocorax beecheii and C. sanblasianus) indicate areas of range overlap.

Among other results, the monophyly of the "Cissilopha" jays is consistent with their shared plumage characters, as well as their geographic distribution in Mexico and Central America, fitting previous hypothesis of relationships (e.g., Amadon, 1944; Goodwin, 1976; Hardy, 1969; Hope, 1989). Although paraphyly of C. sanblasianus with respect to C. beecheii is 
unexpected given their differences in plumage and size, the short internodal branches conducting to $C$. sanblasianus $1+($ C. sanblasianus $2+$ C. beecheii $)$ and C. sanblasianus $2+$ C. beecheii, might indicate that speciation in this group occurred in a relatively short period of time, and not enough synapomorphies accumulated in the mitochondrial genes analyzed herein. This same scenario might also explain the low support for the $C$. sanblasianus $+C$. beecheii clade. Although cases of species paraphyly were once seen as exceptions rather than rules, in recent years the number of studies showing this phenomenon has been directly related to deep scrutiny of sister-species relationships (Johnson and Cicero, 2004), and to analyses including multiple samples per species (Funk and Omland, 2003; for several examples among Neotropical birds see Pérez-Emán, 2005; Weir et al., 2008; DaCosta and Klicka, 2008).

An alternate explanation would be introgression in the area of overlap between Cyanocorax beecheii and C. sanblasianus in western Nayarit (Fig. 4). Although examination of the specimens involved did not reveal any deviations from their expected morphology, hybridization and introgression could have occurred in the history of these species. Occasional reports of hybrids between NWJ species (e.g., Psilorhinus $\times$ Calocitta from western Chiapas, Mexico; Pitelka et al., 1956) suggest that hybridization occurs in the wild. Given that only mitochondrial sequences were available for these taxa, discarding hybridization/introgresion is not possible. Additionally, judging by the relatively low the degree of differentiation observed among our nuclear introns, adding sequences from these loci may prove non-informative.

Most relationships among the South American jays in Group II resulted as expected. The sister relationship of Cyanocorax chrysops and C. cyanopogon is consequent with their early placement in a single species (Hellmayr, 1934). Also, a close relationship between C. chrysops + C. cyanopogon with C. cayanus is consistent with their similar morphology and geographic 
distribution north (C. cayanus) and south (C. chrysops + C. cyanopogon) of the Amazon River (Fig. 4). More interesting from the morphological standpoint is the sister relationship between $C$. heilprini and C. affinis, given that Cyanocorax heilprini differs from all other species in having a dark venter. Finally, the position of C. dickeyi as sister to Group II and the statistical significance of the parametric bootstrapping test, contradict previous hypothesis regarding its close relationship with C. mystacalis (Haemig, 1979; Hope, 1989). This result supports the hypothesis of retention of plesiomorphic plumage characters in C. mystacalis or homoplasy.

\subsection{Biogeography}

The phylogenetic relationships reconstructed herein illustrate why past attempts to understand the biogeography of Cyanocorax and allied genera have been unfruitful and puzzling (e.g., Hardy, 1961; Hardy, 1969; Goodwin, 1976). The general pattern that emerges is one in which relatively recent radiations (e.g., Group II and the “Cissilopha” jays) fit general expectations based on biogeography. However, farther back in evolutionary time, traces of ancestral biogeographic history seem to be lost from the phylogenetic record. Two clear cases of discontinuous geographic distributions are recovered by the phylogeny: (1) Calocitta and Psilorhinus, two species from Mesoamerica, being most closely related to species in the Amazon Basin and central South America (Fig. 5); and (2) C. dickeyi from a minute area of northwestern Mexico, as sister to a clade of mostly South American jays (Fig. 4). 


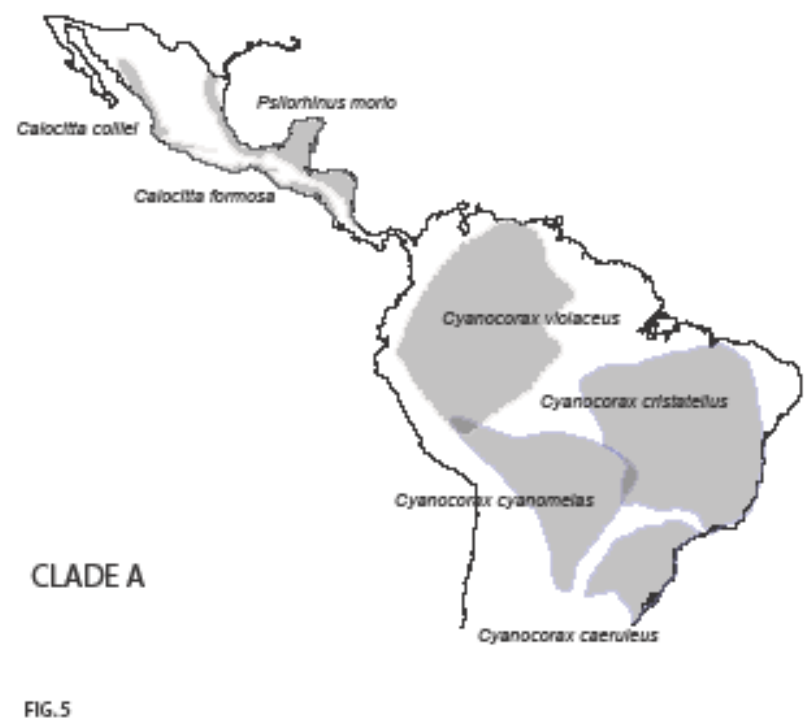

Fig. 5. Geographic distribution of species in Clade A. Darker shades indicated areas of range overlap.

Repeated instances of discontinuous distributions across the phylogeny could be explained by two different processes-i.e., long-distance dispersal or local extinction of widely distributed ancestors. Curiously, some species in this group are known to stray from their customary distributional areas (e.g., C. yncas [Hilty, 2003]), occasionally by hundreds of kilometers (C. sanblasianus in Arizona [Phillips, 1950]; “Cissilopha” sp. in Texas, [J. Eitniear, pers. comm.]). Also among NWJs, the Blue Jay, Cyanocitta cristata, is at least partially migratory in the northern portion of its range (Pitelka, 1946), a pattern repeated in several species of Corvus (Madge and Burn, 1994). As demonstrated for orioles (Kondo and Omland, 2007), New World thrushes (Outlaw et al., 2003), and Old World warblers (Helbig, 2003), migratory behavior may evolve independently across the phylogeny of a group. Nonetheless, the partial or relatively short-distance nature of migrations among corvids makes the possibility of long-distance migration less plausible than in other lineages. 
On the other hand, local extinction of a broadly distributed ancestor has been invoked to explain the peculiar distribution of Cyanocorax dickeyi (Amadon, 1944). In fact, extinction seems to be the most plausible explanation for broad distributional gaps observed in nonmigratory avian taxa, for which reasonable geographic sampling has been accomplished: e.g., the azure-winged magpie (Cyanopica cyanus) disjunct distribution in the Iberian peninsula and Asia, (Fok et al., 2002); wrentits, Chamaea fasciata, from western North America, most closely related to the Old World genus Sylvia (Barhoum and Burns, 2002); and New World and Asian piculets, Picumnus, most closely related to each other (Benz et al., 2006). Among Cyanocorax species, the geographic gap between Mesoamerican and South American populations of C. yncas (Fig. 4), could represent the early stage of a geographic gap produced by local extinction. Given a high potential for extinction, the exercise of reconstructing ancestral areas would be misleading in this case, and could produce simply erroneous results.

\subsection{Taxonomic Implications}

Phylogenetic analysis of species in Cyanocorax and allied genera revealed that Cyanocorax is paraphyletic. This result is well supported by individual-gene and combined analyses, and by the statistical rejection of the null hypothesis of monophyly of the genus. Thus, if phylogenetic relationships are to be reflected in systematic classification, and if taxa are to be natural groups, the genus Cyanocorax must be redefined. From the relationships recovered for the overall assemblage, two different approaches could be taken.

The first option involves maintaining the genus Cyanocorax specifically for species in Clade B-C. chrysops Boie 1826 is the type species (Hellmayr, 1934)—and naming species in Clade A with the next available name, which would be Psilorhinus Ruppell 1838 (Hellmayr, 
1934); this alternative involves changing the genus of six species (Cyanocorax cyanomelas, $C$. cristatellus, C. violaceus, C. caeruleus, Calocitta formosa, C. colliei). The second approach is lumping all taxa into a broader concept of Cyanocorax, given its taxonomic priority; in this case, only three species would change genus (Calocitta formosa, C. colliei, and Psilorhinus morio [according to some classifications]). Because most recent classifications (AOU, 1983, 1998; Dickinson, 2003; Clements, 2007) already submerge Psilorhinus morio into Cyanocorax, placing species of Calocitta within Cyanocorax would be a minimal change in taxonomy.

Based on the phylogenetic results, the monophyletic group including Cyanocorax, Calocitta, and Psilorhinus, is highly diverse from morphological (e.g., Moore, 1935; Amadon, 1944; Hardy, 1969; Hope, 1989), behavioral (Alvarez, 1975; Gayou, 1986; Peterson, 1991), and ecological (e.g., C. heilprini) points of view. Although a previous study (Bonaccorso and Peterson, 2007) discussed the uniqueness of Psilorhinus morio in terms of its possession of a "furcular pouch" (Sutton and Gilberg, 1942), reflecting the actual morphological variation within the overall assemblage would require recognizing a multiplicity of genera: Cyanocorax (Clade B), Calocitta and Psilorhinus (if reciprocally monophyletic and sister to all other species in Clade A), and Uroleuca Bonaparte 1859 (including Cyanocorax cristatellus, C. violaceus, C. cyanomelas, C. caeruleus), if all other species in Clade A formed a monophyletic group.

On the contrary, the merging Psilorhinus and Calocitta into Cyanocorax meets most of the criteria recently proposed for naming monophyletic taxa (Guayasamin et al., 2009), these being: 1) significant statistical support and congruence among phylogenetic estimation methods; 2) congruence (or no conflict) among genetic markers; and 3) traditional use of names, minimizing the number of taxonomic changes (also in ICZN, 1999). A fourth and final criterion, based on morphological and/or behavioral distinctiveness, cannot be applied since, to our 
knowledge, no unreversed morphological/behavioral synapomorphies unite the group (other than the overly general "large, crowlike body form," which is unique among NWJs).

\section{Conclusions}

Analyses of phylogenetic relationships among Cyanocorax, Psilorhinus, and Calocitta, revealed consistent patterns indicating overall monophyly of the group, but paraphyly of the current Cyanocorax. Also, division of ingroup taxa into two reciprocally monophyletic groups, Clades A and B, is highly supported. Within Clade A, a robust node indicates the monophyly of C. violaceus from Peru + C. cristatellus + C. cyanomelas (Group I). Based on previous morphological studies (Hope, 1989), it is possible that this clade includes also C. caeruleus; however, the ambiguous phylogenetic position of C. caeruleus and Psilorhinus morio, and the paraphyly of $C$. violaceus prevent solid conclusions on relationships within this clade. Within Clade B, ambiguous relationships were limited to resolving the positions of $C$. yncas and $C$. mystacalis.

Further resolution of problematic, weakly supported relationships associated with inconsistencies between mitochondrial and nuclear genes (e.g., Psilorhinus and Calocitta), as well as those involving relatively short internodal branches (e.g., the positions of $C$. mystacalis and C. yncas, and C. sanblasianus and C. beecheii), seems difficult at this point. In the case of relationships involving short branches, theoretical models indicate that when the time of shared ancestry is short compared to that of independent ancestry (e.g., short internodal branches leading to long terminal branches), the number of informative characters will be so small that the probabilities of recovering a bifurcating pattern is low (Lanyon, 1988). Moreover, signals of common ancestry (i.e., synapomorphies) are most likely to be overwritten by homoplasy 
(McCracken and Sorenson, 2005). Thus, resolving these relationships might require considerably greater numbers of mitochondrial and fast-evolving nuclear characters.

The phylogenetic complexity of lineages in the current Cyanocorax suggests several complications for the taxonomy of the group. Although multiple taxonomic arrangements are possible, our recommendations are for recognizing a single inclusive genus, Cyanocorax, including species currently assigned to Psilorhinus and Calocitta. This proposition maximizes stability of a systematic classification consistent with phylogeny.

Genealogical patterns recovered in this study highlight the importance of analyzing multiple samples per taxa, particularly as concerns detection of species paraphyly, cryptic species, and ancestral polymorphisms. Still, extensive population-level, multi-locus analyses will be necessary to understand the origin of these patterns. Finally, these results emphasize the importance of collecting and preserving proper voucher specimens when trying to detect coupled genetic and morphological change, as well as traces of hybridization.

\section{Acknowledgments}

We are grateful to D. Dittman, R. Brumfield and J. V. Remsen (LSUMNS), N. Rice (ANSP), S. Hackett and D. E. Willard (FMNH), J. Cracraft and P. Sweet (AMNH), J. Dean (USMNH), K. Bostwick (CUMZ), K. Zyskowski (YPM), and M. B. Robbins (KUNHM) for providing samples under their care, as well as to numerous field collectors for their efforts in providing museum specimens and tissues for systematic studies. For assistance with accumulation of new specimen material, we thank the authorities and our scientific colleagues in Mexico, El Salvador, Guyana, Paraguay, and Argentina. Enrique Arbeláez-Cortés assisted with sequencing the second sample of Cyanocorax beecheii. Nathan Rice provided information on the plumage of 
C. violaceus from Ecuador and Peru. Jeet Sukumaran provided valuable assistance in running analyses on the KUNHM computing cluster. Juan M. Guayasamin, L. Trueb, R. Brown, and two anonymous reviewers made helpful comments on this manuscript. This study was funded by grants from the National Science Foundation (Dissertation Improvement Grant DEB-0508910, to EB and ATP), SENACYT and the AMNH Frank Chapman Memorial Fund (to EB), SEMARNAT-CONACyT (to AGNS), and the Center for Conservation and Evolutionary

Genetics (to RCF). E. B. is thankful to J. M. Guayasamin for his unconditional support and valuable contributions to this work.

\section{References}

AOU, 1983. Check-list of North American birds, 6th ed. American Ornithologists' Union, Washington, D.C.

AOU, 1998. Check-list of North American birds, 7th ed. American Ornithologists' Union, Washington, D.C.

Alvarez, H., 1975. The social system of the Green Jay in Colombia. Living Bird 14, 15-43.

Amadon, D., 1944. The genera of Corvidae and their relationships. Amer. Mus. Nov. 1251, 121.

Amaral, M. F., Macedo, R. H. F., 2003. Breeding patterns and habitat use in the endemic Curlcrested Jay of central Brazil. J. Field Ornithol. 74, 331-340. 
Barhoum, D. N., Burns, K. J., 2002. Phylogenetic relationships of the wrentit based on mitochondrial cytochrome b sequences. Condor 104, 740-749.

Blake, E. R., Vaurie, C., 1962. Family Corvidae. In: Mayr, E., Greenway, J. C. Jr. (Eds.), Checklist of birds of the world, Vol. 15. Mus. Comp. Zool. Cambridge, Massachusetts, pp. 204282.

Benz, B. W., Robbins, M. B., Peterson, A. T., 2006. Evolutionary history of woodpeckers and allies (Aves: Picidae): Placing key taxa on the phylogenetic tree. Mol. Phyl. Evol. 40, 389399.

Bonaccorso, E., Peterson, A. T., 2007. A multilocus phylogeny of New World jay genera. Mol. Phyl. Evol. 42, 467-476.

Bonaccorso, E., 2009. Historical biogeography and speciation in the Neotropical highlands: Molecular phylogenetics of the jay genus Cyanolyca. Mol. Phyl. Evol. 50, 618-632.

Bull, J., Huelsenbeck, J. P., Cunningham, C. W., Swofford, D. L., Waddel, P. J., 1993. Partitioning and combining data in phylogenetic analysis. Syst. Biol. 42, 384-397.

Cicero, C., Johnson, N. K., 2001. Higher level phylogeny of vireos (Aves: Vireonidae) based on sequences of multiple mtDNA genes. Mol. Phylogenet. Evol. 20, 27-40.

Clements, J. F., 2007. The Clements Checklist of Birds of the World. Cornell Univ. Press, Ithaca, New York.

Crossin, R. S., 1967. The breeding biology of the Tufted Jay. Proc.Western Found. Vert. Zool. 1, 265-299.

DaCosta J. M., Klicka, J., 2008. The Great American Interchange in birds: A phylogenetic perspective with the genus Trogon. Mol. Ecol. 17, 1328-1343. 
de Queiroz, A., Donoghue, M. J., Kim, J., 1995. Separate versus combined analysis of phylogenetic evidence. Annu. Rev. Ecol. Syst. 26, 657-681.

Dickinson, E., 2003. The Howard \& Moore Complete Checklist of the Birds of the World. 3d ed. Princeton Univ. Press, Princeton, New Jersey.

Effron, B., 1985. Bootstrap confidence intervals for a class of parametric problems. Biometrika 73, 45-58.

Ericson, P. G. P., Jansén, A. L., Johansson, U. S., Ekman, J., 2005. Inter-generic relationships of the crows, jays, magpies and allied groups (Aves: Corvidae) based on nucleotide sequence data. J. Avian Biol. 36, 222-234.

Espinosa de los Monteros, A., Cracraft, J., 1997. Intergeneric relationships of the New World jays inferred from cytochrome b gene sequences. Condor 99, 490-502.

Felsenstein, J., 1981. Evolutionary trees from DNA sequences: A maximum likelihood approach. J. Mol. Evol. 17, 368-376.

Felsenstein, J., 1985. Confidence limits in phylogenies: An approach using the bootstrap. Evolution 39, 783-791.

Felsenstein, J., 1988. Phylogenies from molecular sequences: Inference and reliability. Annu. Rev. Genet. 22, 521-565.

Fleischer, R.C., Olson, S., James, H. F., Cooper, A. C., 2000. The identity of the extinct Hawaiian eagle (Haliaeetus) as determined by mitochondrial DNA sequence. Auk 117, 1051-1056.

Fleischer, R.C., Tarr, C. L., James, H. F., Slikas, B., McIntosh, C. E., 2001. Phylogenetic placement of the po`o-uli (Melamprosops phaeosoma) based on mitochondrial DNA sequence and 466 osteological characters. Stud.Avian Biol. 22, 98-103. 
Fok, K. W., Wade, C. M., Parkin, D. T., 2002. Inferring the phylogeny of disjunct populations of the azure-winged magpie Cyanopica cyanus from mitochondrial control region sequences. Proc. R. Soc. London B 269, 1671-1679.

Funk, D. J., Omland, K. E., 2003. Species-level paraphyly and polyphyly: Frequency, causes, and consequences, with insights from animal mitochondrial DNA. Annu. Rev. Ecol. Evol. Syst. 34, 397-423.

Gayou, D. C., 1986. The social system of the Texas Green Jay. Auk 103, 540-547.

Gene Codes Corporation, 2000. Sequencher Version 4.1. Gene Codes Corporation, Ann Arbor, Michigan.

Goodwin, D., 1976. Crows of the World. Cornell Univ. Press, Ithaca, New York.

Guayasamin, J. M., Castroviejo-Fisher, S., Trueb, L., Ayarzagüena, J., Rada, M., Vilà, C., 2009. Phylogenetic systematics of glassfrogs (Amphibia: Centrolenidae) and their sister taxon Allophryne ruthveni. Zootaxa 2100, 1-97.

Haemig, P. D., 1979. Secret of the Painted Jay. Biotropica 11, 81-87.

Hardy, J. W., 1961. Studies in behavior and phylogeny of certain New World jays (Garrulinae). Univ. Kansas Sci. Bull. 42, 13-149.

Hardy, J. W., 1969. Habits and habitats of certain South American jays. Cont.Sci., Nat. Hist. Mus. Los Angeles Co., 165, 1-16.

Hardy, J. W., 1973. Age and sex differences in the black-and-blue jays of Middle America. Bird Banding 44, 81-90.

Hardy, J. W., 1974. Behavior and its evolution in Neotropical jays (Cissilopha). Bird Banding 45, 253-268. 
Hardy, J. W., 1979. Vocal repertoire and its possible evolution in the black and blue Jays (Cissilopha). Wilson Bull. 91, 187-201.

Helbig, A. J., 2003.Evolution of bird migration: A phylogenetic and biogeographic perspective. In: Berthold P., Gwinner E., Sonnenschein E., (Eds). Avian Migration. Springer, Berlin, pp $3-20$.

Hellmayr, C. E., 1934. Catalogue of the Birds of the Americas and the Adjacent Islands. Field Museum of Natural History, Chicago.

Helm-Bychowski, K., Cracraft, J., 1993. Recovering phylogenetic signal from DNA sequences: Relationships within the corvine assemblage (Class Aves) as inferred from complete sequences of the mitochondrial DNA cytochrome-b gene. Mol. Biol. Evol. 10, 1196-1214.

Hilty, S. L., 2003. Birds of Venezuela. Princeton University Press, Princeton, New Jersey. Hope, S., 1989. Phylogeny of the Avian Family Corvidae. Ph. D. dissertation, City University of New York, New York, New York.

Huelsenbeck, J. P., Hillis, D. M., Nielsen, R., 1996a. A likelihood-ratio test of monophyly. Syst. Biol. 45, 546-558.

Huelsenbeck, J. P., Hillis, D. M., Jones, R., 1996b. Parametric bootstrapping in molecular phylogenetics: Applications and performance. In: Ferraris, J. D., Palumbi, S. R. (Eds.), Molecular Zoology: Advances, Strategies, and Protocols. Wiley-Liss, New York, pp. 19-45.

ICZN, 1999. International Code of Zoological Nomenclature, ed 4. International Trust for Zoological Nomenclature, London.

Johnson N. K., Cicero, C., 2004. New mitochondrial DNA data affirm the importance of Pleistocene speciation in North American birds. Evolution 58, 1122-1130. 
Kocher, T. D., Thomas, W. K., Meyer, A., Edwards, S. V., Pääbo, S., Villablanca, F. X., Wilson, A. C., 1989. Dynamics of mitochondrial DNA evolution in animals: Amplification and sequencing with conserved primers. Proc. Nat. Acad. Sci. USA 86, 6196-6200.

Kondo, B., Omland, K. E., 2007. Ancestral state reconstruction of migration: Multistate analysis reveals rapid changes in New World orioles. Auk, 410-419.

Langen, T. A., 1996. The mating system of the white-throated magpie-jay Calocitta formosa and Greenwood's hypothesis for sex-biased dispersal. Ibis 138, 506-513.

Lanyon, S. M., 1988. The stochastic mode of molecular evolution: What consequences for systematic investigations? Auk 105, 565-573.

McCracken, K. G., Sorenson, M. D., 2005. Is homoplasy or lineage sorting the source of incongruent mtDNA and nuclear gene trees in the stiff-tailed ducks (Nomonyx-Oxyura)? Syst. Biol. 54, 35-55.

Maddison, D. R., Maddison, W. P., 2000. MacClade: Analysis of Phylogeny and Character Evolution. Ver. 4.0. Sinauer, Sunderland, Massachusetts.

Maddison, D. R., Maddison, W. P., 2004a. Batch Architect: Automation of Simulations and Replicated Analyses. A package of modules for Mesquite. Ver. 1.01. Available from: http://mesquiteproject.org/mesquite/download/download.html

Maddison, W. P., Maddison, D. R., 2004b. Mesquite: A Modular System for Evolutionary Analysis Ver. 1.05. Available from:

\section{http://mesquiteproject.org/mesquite/download/download.html}

Madge, S., Burn, H., 1994. Crows and Jays: A Guide to the Crows, Jays, and Magpies of the World. Houghton Mifflin Co., Boston and New York. 
Meyer de Schauensee, R., 1966. The Species of Birds of South America and their Distribution. Livingston Publishing Co., Narberth, Pennsylvania.

Monroe, B. L., Sibley, C. G., 1993. A World Checklist of Birds. Yale University Press, New Haven and London.

Moore, R. T., 1935. A new jay of the genus Cyanocorax from Sinaloa, Mexico. Auk 52, 274277.

Outlaw, D. C., Voelker, G., Mila, B., Girman, D. J., 2003. Evolution of long-distance migration and historical biogeography of Catharus thrushes: A molecular approach. Auk 120, 299-310.

Pérez-Emán, J., 2005. Molecular phylogenetics and biogeography of the Neotropical redstarts (Myioborus: Aves, Parulinae). Mol. Phylogenet. Evol. 37, 511-528.

Peterson, A. T., 1991. Sociality and ontogeny of coloration in the blue-and-black jays (Cyanocorax). Wilson Bull. 103, 59-67.

Phillips, A. R., 1950. The San Blas Jay in Arizona. Condor 52, 86.

Pitelka, F. A., 1946. Age in relation to migration in the Blue Jay. Auk 63, 82-84.

Pitelka, F. A., Selander, R. K., Alvarez Del Toro, M., 1956. A hybrid jay from Chiapas, Mexico. Condor 58, 98-106.

Posada, D., Crandall, K. A., 1998. MODELTEST: Testing the model of DNA substitution. Bioinformatics 14, 817-818.

Posada, D., Crandall, K. A., 2001. Selecting the best-fit model of nucleotide substitution. Syst. Biol. 50, 580-601.

Prychitko, T. M., Moore, W. S., 1997. The utility of DNA sequences of an intron from the $\beta$ fibrinogen gene in phylogenetic analysis of woodpeckers (Aves: Picidae). Mol. Phylogenet. Evol. 8, 193-204. 
Raitt, R. J., Hardy, J. W., 1976. Behavioral ecology of the Yucatan Jay. Wilson Bull. 88, 529_ 721.

Raitt, R. J., Hardy, J. W., 1979. Social behavior, habitat, and food of the Beechey Jay. Wilson Bull. 91, 1-15.

Rambaut, A., Drummond A. J., 2004. Tracer 1.3 [computer program] Available at: http://evolve.zoo.ox.ac.uk/software.html

Ridgely, R. S., Tudor, G., 1989. The Birds of South America, Vol. 1. University of Texas Press, Austin.

Ridgely, R. S., Greenfield, P. J., 2001. The Birds of Ecuador. Vol. I. Status, Distribution, and Taxonomy. Cornell University Press, Ithaca, New York.

Ronquist, F., Huelsenbeck, J. P., 2003. MrBayes 3: Bayesian phylogenetic inference under mixed models. Bioinformatics 19, 1572-1574.

Saunders, M. A., Edwards, S. V., 2000. Dynamics and phylogenetic implications of mtDNA control region sequences in New World jays (Aves: Corvidae). J. Mol. Evol. 51, 97-109.

Shapiro, L. H., Dumbacher, J. P., 2001. Adenylate kinase intron 5: A new nuclear locus for avian systematics. Auk 118, 248-255.

Sokal, R. R., Rohlf, F. J., 1995. Biometry: The Principles and Practice of Statistics in Biological Research, 3rd ed. W. H. Freeman and Co., New York.

Sorenson, M. D., Ast, J. C., Dimcheff, D. E., Yuri, T., Mindell, D. P., 1999. Primers for a PCRbased approach to mitochondrial genome sequencing in birds and other vertebrates. Mol. Phylogenet. Evol. 12, 105-114.

Sorenson, M. D., Balakrishnan, C. N., Payne, R. B., 2004. Clade-limited colonization in brood parasitic finches (Vidua spp.). Syst. Biol. 53, 140-153. 
Sutton, J. M., Gilbert, P. W., 1942. The Brown Jay’s furcular pouch. Condor 44, 160-165.

Swofford, D. L., 2002. PAUP* 4.0b10: Phylogenetic Analysis using Parsimony (* and other methods). Sinauer, Sunderland.

Thompson, J. D., Gibson, T. J., Plewniak, F., Jeanmougin, F., Higgins, D. G., 1997. The CLUSTAL_X windows interface: Flexible strategies for multiple sequence alignment aided by quality analysis tools. Nucl. Acids Res. 25, 4876-4882.

Weir, J. T., E. Bermingham, Miller, M. J., Klicka, J., González, M. A., 2008. Phylogeography of a morphologically diverse Neotropical montane species, the Common Bush-Tanager (Chlorospingus ophthalmicus). Mol. Phylogenet. Evol. 47, 650-664.

Wiens, J. J., 1998. Combining data sets with different phylogenetic histories. Syst. Biol. 47, 568581.

Wiley, E. O., 1978. The evolutionary species concept reconsidered. Syst. Zool. 27, 17-26.

Wilgenbusch, J. C., Warren, D. L., Swofford, D. L., 2004. AWTY: A System for Graphical Exploration of MCMC Convergence in Bayesian Phylogenetic Inference. http://ceb.csit.fsu.edu/awty.

Zwickl, D. J., 2006. Genetic Algorithm Approaches for the Phylogenetic Analysis of Large Biological Sequence Datasets under the Maximum Likelihood Criterion. Ph. D. dissertation, University of Texas, Austin. 
Appendix I. Internal primers used to amplify sequences from museum study skin samples.

\begin{tabular}{ll}
\hline Gene & Primers \\
\hline ND2 & L350 CAT CGA AGC AGC YAC TAA RTA YTT CC \\
L449 TGA ATA GGA CTA AAY CAA ACA C \\
L493 GGA GGA TGA ATA GGA CTA AAC \\
L664 ATG AAA GTY CTA AAA CTA TCA ACR C \\
L835 GCA ATA ATC ATY TCA CTT CTG TC \\
H200 GAG GCA GCT TGT ACY ARG \\
H416 ATT GGT GGG AAT TTY ATY ACY GTG G \\
H574 TAG CTA TTC AGC CCA GGT GAG CAA \\
H727 TTG TGC TAA GTG AAG GTG \\
H903 TGT TGC RCA GTA TGC TAG GCG AAG \\
L691 CTA GGA TTY GCA CTA ATR CTA RTC CTA C \\
L939 ACG CTC AAT AAC CTT CCG TC \\
H998 AGG TCT GCA ACT AGK GTT CAR AAT AG \\
cytb
\end{tabular}

Appendix II. Mitochondrial (cytb) maximum likelihood-corrected pair-wise distances (substitutions per site) among Cyanocorax species. Distances for species for which DNA was extracted from skins or degraded samples (C. heilprini, C. caeruleus, C. beecheii, C. sanblasianus) are not included, given considerable amounts of missing data.

\begin{tabular}{|c|c|c|c|c|c|c|c|c|c|c|c|c|c|c|c|c|c|}
\hline & Species & 1 & 2 & 3 & 4 & 5 & 6 & 7 & 8 & 9 & 10 & 11 & 12 & 13 & 14 & 15 & 16 \\
\hline 1 & Cyanocorax cayanus 1 & & & & & & & & & & & & & & & & \\
\hline 2 & C. cyanomelas 6 & 0.20 & & & & & & & & & & & & & & & \\
\hline 3 & C. chrysops 13 & 0.08 & 0.19 & & & & & & & & & & & & & & \\
\hline 4 & C. affinis 20 & 0.07 & 0.19 & 0.08 & & & & & & & & & & & & & \\
\hline 5 & C. mystacalis 26 & 0.12 & 0.21 & 0.14 & 0.13 & & & & & & & & & & & & \\
\hline 6 & C. cyanopogon 28 & 0.07 & 0.20 & 0.06 & 0.08 & 0.13 & & & & & & & & & & & \\
\hline 7 & C. violaceus 29 & 0.19 & 0.03 & 0.20 & 0.20 & 0.20 & 0.20 & & & & & & & & & & \\
\hline 8 & C. violaceus 31 & 0.19 & 0.07 & 0.21 & 0.20 & 0.20 & 0.21 & 0.07 & & & & & & & & & \\
\hline 9 & C. cristatellus 33 & 0.20 & 0.03 & 0.22 & 0.21 & 0.20 & 0.22 & 0.03 & 0.07 & & & & & & & & \\
\hline 10 & C. dickeyi 33s & 0.08 & 0.19 & 0.09 & 0.07 & 0.13 & 0.09 & 0.20 & 0.21 & 0.21 & & & & & & & \\
\hline 11 & C. yncas 36 & 0.17 & 0.25 & 0.19 & 0.15 & 0.17 & 0.19 & 0.24 & 0.24 & 0.25 & 0.16 & & & & & & \\
\hline 12 & C. yncas 40 & 0.19 & 0.23 & 0.19 & 0.17 & 0.18 & 0.19 & 0.23 & 0.24 & 0.25 & 0.16 & 0.08 & & & & & \\
\hline 13 & C. yucatanicus 42 & 0.11 & 0.23 & 0.12 & 0.12 & 0.15 & 0.13 & 0.23 & 0.22 & 0.23 & 0.11 & 0.17 & 0.18 & & & & \\
\hline 14 & C. melanocyaneus 43 & 0.11 & 0.23 & 0.11 & 0.12 & 0.14 & 0.12 & 0.23 & 0.24 & 0.24 & 0.11 & 0.17 & 0.15 & 0.09 & & & \\
\hline 15 & P. silorhinus 45 & 0.23 & 0.10 & 0.24 & 0.21 & 0.23 & 0.25 & 0.09 & 0.12 & 0.10 & 0.20 & 0.28 & 0.30 & 0.23 & 0.26 & & \\
\hline 16 & C. formosa & 0.25 & 0.10 & 0.27 & 0.26 & 0.26 & 0.25 & 0.10 & 0.11 & 0.10 & 0.27 & 0.31 & 0.31 & 0.30 & 0.28 & 0.14 & \\
\hline 17 & C. colliei & 0.20 & 0.08 & 0.22 & 0.22 & 0.22 & 0.23 & 0.07 & 0.09 & 0.07 & 0.23 & 0.28 & 0.27 & 0.25 & 0.24 & 0.11 & 0.09 \\
\hline
\end{tabular}

